\title{
Vegetation History in the Toledo Mountains (Central Iberia): Human Impact during the Last 1300 Years
}

\author{
Reyes Luelmo-Lautenschlaeger ${ }^{1,2, *(\mathbb{D})}$, Sebastián Pérez-Díaz ${ }^{1}$, Francisca Alba-Sánchez ${ }^{3}$ (D), \\ Daniel Abel-Schaad ${ }^{3}$ (iD and José Antonio López-Sáez ${ }^{1}$ \\ 1 G.I. Arqueobiología, Instituto de Historia (CCHS), CSIC, Albasanz 26-28, 28037 Madrid, Spain; \\ sebas.perezdiaz@gmail.com (S.P.-D.); joseantonio.lopez@cchs.csic.es (J.A.L.-S.) \\ 2 Departamento de Geografía, Facultad de Filosofía y Letras, Universidad Autónoma de Madrid, 28049 \\ Madrid, Spain \\ 3 Departamento de Botánica, Facultad de Ciencias, Universidad de Granada, 18071 Granada, Spain; \\ falba@ugr.es (F.A.-S.); dabel222@hotmail.com (D.A.-S.) \\ * Correspondence: reyes.luelmo@gmail.com
}

Received: 22 June 2018; Accepted: 18 July 2018; Published: 23 July 2018

\begin{abstract}
Mid-mountain ecosystems provide a broad diversity of resources, heterogeneous relief, and a mild climate, which are all very useful for human necessities. These features enable different strategies such as the terracing of the slopes as well as wide crop diversification. Their relations lead to a parallel co-evolution between the environment and human societies, where fire and grazing become the most effective landscape management tools. This paper presents the results obtained from a multi-proxy study of the Bermú paleoenvironmental record, which is a minerotrophic mire located in the Quintos de Mora National Hunting Reserve (Toledo Mountains, central Spain). The bottom of this core has been dated in the Islamic period (ca. 711-1100 cal AD), and the study shows how the landscape that was built over time in the Toledo Mountains up to the present day is narrowly linked to human development. This study shows the increasing human pressure on the landscape, as well as the subsequent strategies followed by the plant and human communities as they faced diverse environmental changes. Thus, it is possible to attest the main role played by the humans in the Toledo Mountains, not only as a simple user, but also as a builder of their own reflexion in the environment.
\end{abstract}

Keywords: mid-mountains; paleoecology; Late Holocene; central Spain

\section{Introduction}

Mountain ecosystems are usually quite isolated spaces that are difficult to access, with particular features and dynamics according to their own nature, topography, and climatic conditions. Despite this, they show a high biodiversity and attractive wide resource richness that meet human requirements [1-4]. This interaction unleashes continuous changes in mountain landscapes, which generate adaptive strategies, leading to a parallel co-evolution with human societies [5].

This shared evolution has been usually determined by human demography. This has varied depending on climate change, natural disturbances, and human history. Therefore, it has not been a linear, continuous, or uniform process, but it has suffered shrinking and regressions. Human activities began to draw an impact in the environment in the Western Mediterranean Region ca. $5500 \mathrm{cal}$ BC. The sharpest influence ever seen was reached during the "industrial period" [3,6,7]. Since the beginning, fire has been the most effective management tool, and became essential in human history since it has had unequal effects on different forests depending on their nature, height, or age [8,9]. It generated open areas that were used for human habitat, crop cultivation, or grazing. These activities had deep consequences on the forest cover, such as deforestation or soil erosion. Humans have used 
woodlands for survival, getting building materials and fuel (firewood, charcoal, stubble ... ), but also for hunting or apiculture. Along with climatic events over centuries, they have drawn a high-value cultural landscape $[4,10,11]$.

Paleoecological research studies, along with modern pollen rain studies [12-15] are one of the best tools to understand this complex process. Quite a few paleoecological studies have been carried out in the high-mountain spaces of the Iberian Peninsula, from the Pyrenees (e.g., [16]) to the Cantabrian mountains (e.g., $[17,18])$ including the Spanish Central System (e.g., $[19,20])$ among others, composing a very complete knowledge about these mountain ecosystems. However, despite many studies carried out in some European mid-mountain ranges (e.g., [21,22]), these ecosystems have been less studied, as Sancho-Reinoso [23] recognized. Although the term "mid-mountain" has been widely used, the characterization of this environment has been always been built in contrast with lowlands and high-mountain spaces [24]. The main criteria that has been used to define these spaces has been the kind of relief and the altitude, forgetting about climatic, biological, and land-use features [24,25]. Mid-mountain ecosystems show a high diversity of resources, based on a heterogeneous relief and a mild climate that allows a number of strategies such as terracing the slopes or a huge crop variety. Therefore, it's so easy to find human traces: not only deforestation and soil erosion, but also activities made over the slopes with a terrace-based systemand other elements performed in order to reduce the effort and make it easier to work in a mean environment $[23,25,26]$.

This dynamic is perfectly traceable in the Toledo Mountains, which is one of the best spots for these kinds of studies. Besides, they are nearly crossed by many main cattle roads such as the Cañada Real Leonesa and the Cañada Real Segoviana, as well as other important paths that are now placed in the current road network $[27,28]$. In spite of this interesting position and the rich anthropogenic evidence in this area, paleoecological studies are scarce and unlinked in this area, although they highlight the diversity, richness, and hazards present in the territory [29-31]. The current vegetation shows important ecological, natural, socio-economical, and cultural unarguable values that make the Toledo Mountains' landscape a complex and changing reality that needs understanding and protection in order to assure its identity.

According to the above, this work presents the results obtained from the study of Bermú mire and compares them with other pollen records in the Toledo Mountains. The main aim of this study is to understand the landscape evolution and the role played by humans and climatic processes during the late Holocene. This study delves into the vegetation dynamics and other natural processes that happened in this area, as well as the relationship between human and plant communities focusing on the important natural and cultural heritage currently present there.

\section{Study Area}

Bermú mire (783 m a.s.l., $\left.39^{\circ} 26^{\prime} 2.71^{\prime \prime} \mathrm{N}, 4^{\circ} 8^{\prime} 45.67^{\prime \prime} \mathrm{W}\right)$ (Figure 1) is located in the southern slope of the Torneros range (Los Yébenes, Toledo, Spain), inside Los Quintos de Mora. Bermú is a minerotrophic mire placed in a property hunting reserve (since 1942), and a privileged witness of the consequences of anthropic management. In addition, the mire lies at the oriental border of the Toledo Mountains, so it presents an intense Mediterranean influence.

The Toledo Mountains are located in the center of Iberian Peninsula, on the southern plateau, separating the Tagus and Guadiana basins. Geologically, this area is part of the western half of the Iberian Hercynian Massif, which was formed during the Ordovician period, and whose main reliefs were originated during the Hesperian Orogeny and later uplifted by the Alpine Orogeny [32]. The landscape is of an Appalachian type, with low ranges (Rocigalgo is the highest massif with $1448 \mathrm{~m}$ a.s.l.; medium altitude, $800-1100 \mathrm{~m}$ a.s.1.) and alluvial valleys. The space between these mountainous reliefs, the alluvial layer called "rañas", is where the less resistant materials such as slates or quartzite sandstones were deposited. Soils are acid and not very fertile [32,33]. The study site is located close to one of those alluvial layers (raña) in the Torneros range. The climate of Bermú mire typically has 
dry and warm summers, and an oceanic influence on the western side of the massif. The average temperature is $17^{\circ} \mathrm{C}$, and the annual precipitation range is $600 \mathrm{~mm}$ to $800 \mathrm{~mm}[31,33]$.

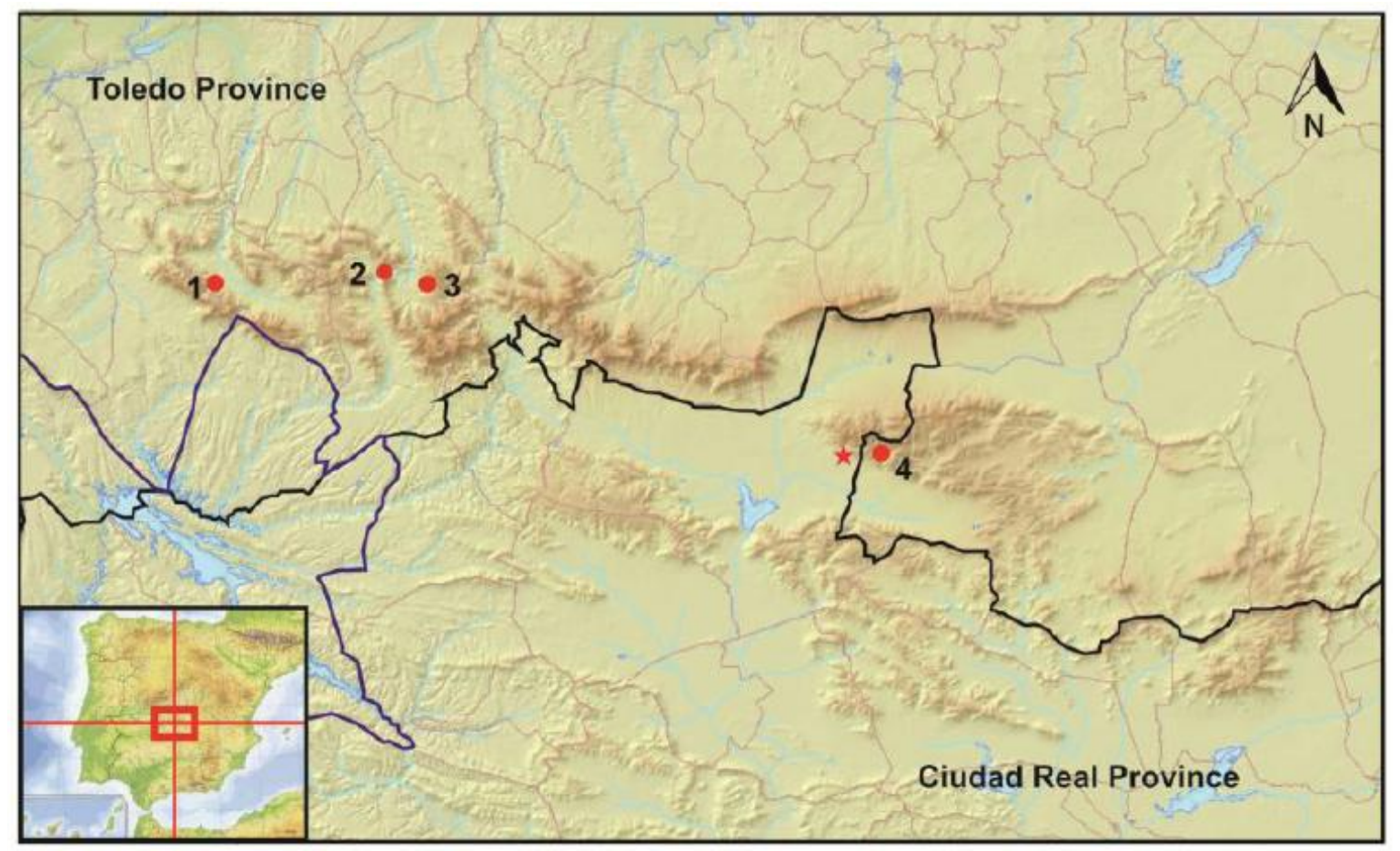

Figure 1. Map of Bermú mire location in the Toledo Mountains (red star) and other mires mentioned in the text (red points): 1. Las Lanchas; 2. Patateros; 3. La Botija; 4. Valdeyernos.

The current vegetation is mainly composed by holm oak (Quercus ilex) and cork oak (Q. suber) forests in the meso-Mediterranean foothills. The first forest type includes mesothermophilous taxa such as Arbutus unedo, Phillyrea angustifolia, Pistacia terebinthus, and Pyrus bourgaeana. The second ones are associated with deciduous trees such as Quercus faginea subsp. broteroi, Q. pyrenaica, and Acer monspessulanum. The supra-Mediterranean belt (>900 m a.s.l.) is composed of deciduous oak forests of Quercus pyrenaica $[31,33,34]$. We can also find some relict species in this area such as Corylus avellana, Betula pendula, or B. pubescens [35-37]. In the mire surroundings, we can find Erica tetralix, Dactylorhiza elata subsp. sesquipedalis, Drosera rotundifolia, Lobelia urens, and Sphagnum capillifolium.

\section{Material and Methods}

\subsection{Sampling and Chronology}

A 72-cm deep core was collected using a Russian peat corer (50-cm long and $5 \mathrm{~cm}$ in diameter). Peat sections were placed in plastic tubes, protected in plastic guttering, and stored under cold conditions $\left(4^{\circ} \mathrm{C}\right)$ prior to laboratory sub-sampling and analysis. The core was sectioned into continuous $1-\mathrm{cm}$ thick portions. The core stratigraphy consists of five parts that are mainly composed of peat and little gravels (Figure 2).

Eight bulk organic sediment samples were ${ }^{14} \mathrm{C}$ dated using the Accelerator Mass Spectrometry technique (onwards AMS). The AMS dating was conducted at Centro Nacional de Aceleradores (Seville, Spain) and the Poznań Radiocarbon Laboratory (Poznán, Poland). The dates were calibrated using CALIB 7.1 with the IntCal13 curve [38], except for the most recent sample, which was calibrated using the CALIBomb program with the calibration dataset NH zone 1 [39] (Table 1). An age-depth model (Figure 2) was produced using Clam 2.2 software [40]. The best fit was obtained applying a smoothing spline to the available radiocarbon dates. Confidence intervals of the calibrations and the 


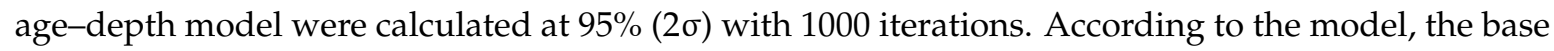
of the 72-cm core corresponds to the Islamic period (711 cal AD), and the sequence extends up to the present day without any recorded sedimentary hiatus.

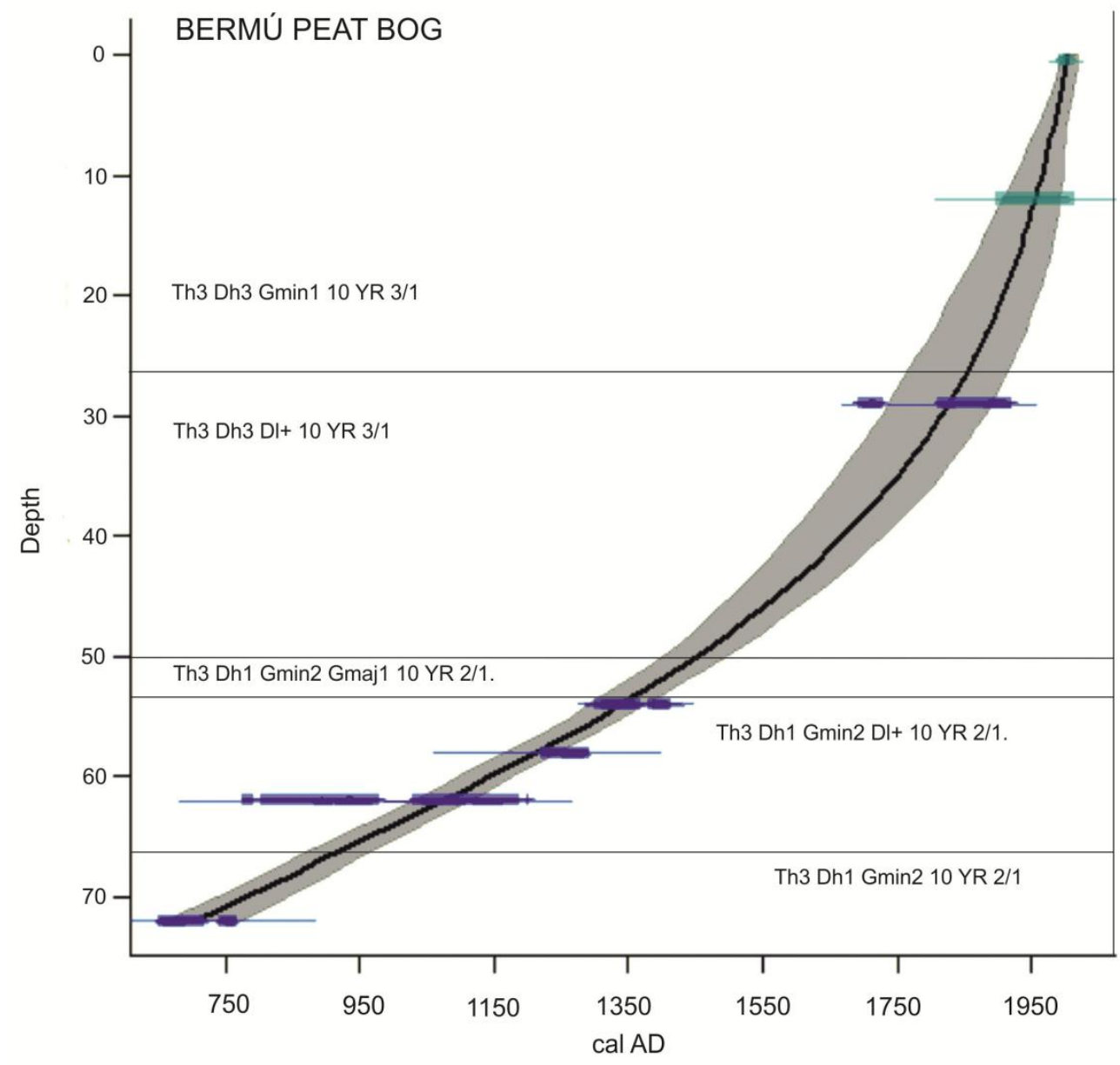

Figure 2. Age-depth model of Bermú mire. Lithostratigraphic description according to Aaby and Berglund [41].

Table 1. AMS radiocarbon data with $2 \sigma$ range of calibration from Bermú mire. (Before Present Age timescale, years before 1950)

\begin{tabular}{ccccc}
\hline Depth $(\mathbf{c m})$ & Laboratory Code & BP Age & Calibrated AD Age & Median Probability Cal AD \\
\hline 12 & CNA-723 & $114.47 \pm 0.38$ & $1958-1994$ & 1992 \\
29 & CNA-724 & $75 \pm 30$ & $1692-1920$ & 1847 \\
44 & CNA-725 & $335 \pm 30$ & $1691-1923$ & 1560 \\
54 & CNA-726 & $558 \pm 30$ & $1474-1640$ & 1346 \\
58 & CNA-2150 & $745 \pm 35$ & $1299-1415$ & 1265 \\
62 & CNA-727 & $915 \pm 35$ & $1219-1293$ & 1105 \\
67 & CNA-2151 & $1140 \pm 35$ & $1029-1204$ & 904 \\
72 & CNA-094 & $1327 \pm 32$ & $649-767$ & 711 \\
\hline
\end{tabular}

\subsection{Pollen Analysis}

Pollen analysis was carried out on 72 sub-samples of $1 \mathrm{~cm}^{3}$ along the core length. All of the samples were treated chemically $(\mathrm{HCl}, \mathrm{KOH}, \mathrm{HF})$ following the standard procedures described by Moore et al. [42], using Thoulet solution for the densimetric extraction of pollen and non-pollen microfossils [43]. Acetolysis was not carried out to allow the identification of any contamination by modern pollen. Macrofossils were not discerned throughout the core. Palynomorphs were identified 
by the use of the reference collection of the Institute of History of the Consejo Superior Iinvestigaciones Científicas (onwards CSIC) (Madrid), and diverse identification keys and photo atlases [42,44-47]. Erica pollen was discriminated following Mateus [48], while Betula and Corylus pollen types were identified according to Blackmore et al. [49]. Anthropogenic Pollen Indicators were designed following Mercuri et al. [50] and López-Sáez et al. [13]. Pollen concentration (grains $\mathrm{cm}^{-3}$ ) was estimated by adding a Lycopodium tablet to each sample [51]. Pollen counts of up to 500 grains of total land pollen per sample were identified and counted. Pollen of aquatic or wetland plants as well as spores, non-pollen palynomorphs (NPPs), and Erica tetralix were excluded from the pollen sum. The pollen and summary diagrams have been plotted against age using TGview [52]. To establish the zonation of the pollen sequence, we tested several divisive and agglomerative methods with the program IBM SPSS Statistics 21. Based on the ecological meaning of the obtained zones, eight local pollen assemblage zones (LPAZ-1 to LPAZ-8) were constructed on the basis of agglomerative constrained cluster analysis of an incremental sum of squares (Coniss) with square root transformed percentage data [53]. The number of statistically significant zones was determined using the broken-stick model [54].

\subsection{Charcoal Analysis}

Charcoal particles were counted under a microscope along with the identification of pollen. The findings were classified into $>125 \mu \mathrm{m}$ and $<125 \mu \mathrm{m}$, indicating local and regional fires, respectively [55,56]. Both are shown in the figures in spite of their strong correlation [57]. Charcoal accumulation rate (CHAR) was calculated by sedimentation rate $\left(\mathrm{cm} \mathrm{year}^{-1}\right)$, and is expressed in particles $\mathrm{cm}^{-2}$ year ${ }^{-1}$ [58]. It is noted that the treatment process can split original large charcoal remains into smaller pieces. Nevertheless, as all of the samples were treated with the same procedure, we assume that this systematic bias was uniform and did not influence the variation of charcoal abundance. Many studies comparing the sieving charcoal series versus the pollen-slide charcoal series showed that both of them display a similar pattern [59].

\section{Results and Discussion}

Thirty-four samples were studied identifying pollen, spores, and non-pollen palynomorphs (NPPs onwards). The results are presented on diagrams (Figures 3-5), where tree and shrub taxa are grouped according to their modern distribution. Herbs and NPPs were classified based on their ecological affinities. The percentage pollen diagrams can be divided into two pollen zones: (i) Bermú-1 (onwards $\mathrm{BM}$ ), from the bottom of the record at $72 \mathrm{~cm}$ depth to $24 \mathrm{~cm}$ depth, and (ii) BM-2, from the $24 \mathrm{~cm}$ depth to the top of the record. The first one is also divisible into four different pollen sub-zones: BM-1.1. (72-62 cm; ca. $711-1100 \mathrm{cal}$ AD); BM 1.2. (62-50 cm; ca. 1100-1450 cal AD); BM. 1.3. (50-38 cm; ca. $1450-1703 \mathrm{cal}$ AD); and BM 1.4. (38-24 cm; ca. 1703-1876 cal AD). 


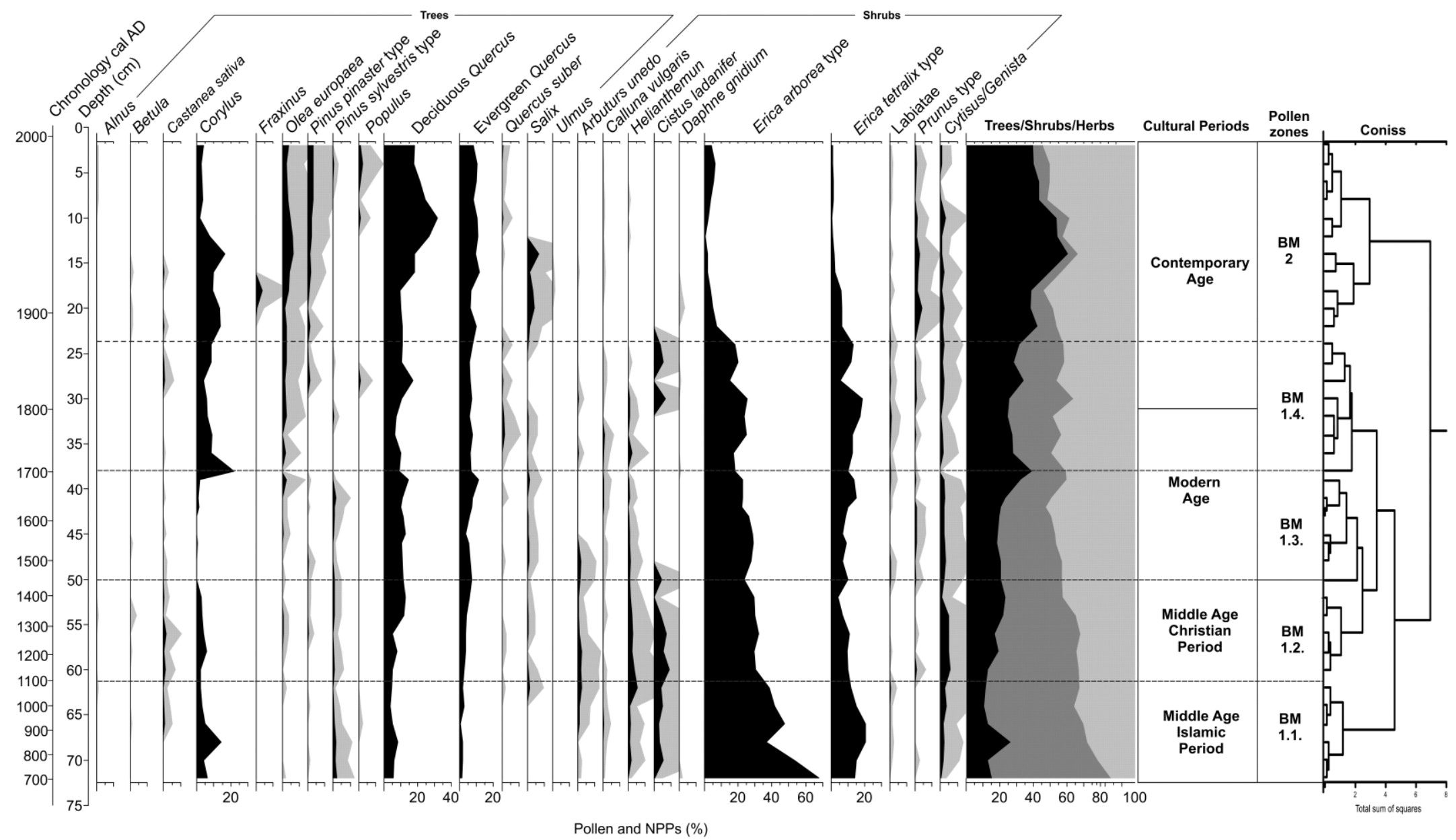

Figure 3. Bermú mire trees and shrubs pollen diagram plotted against depth. The black silhouettes show the percentage curves of the taxa; the grey silhouettes show the $\times 5$ exaggeration curves. 


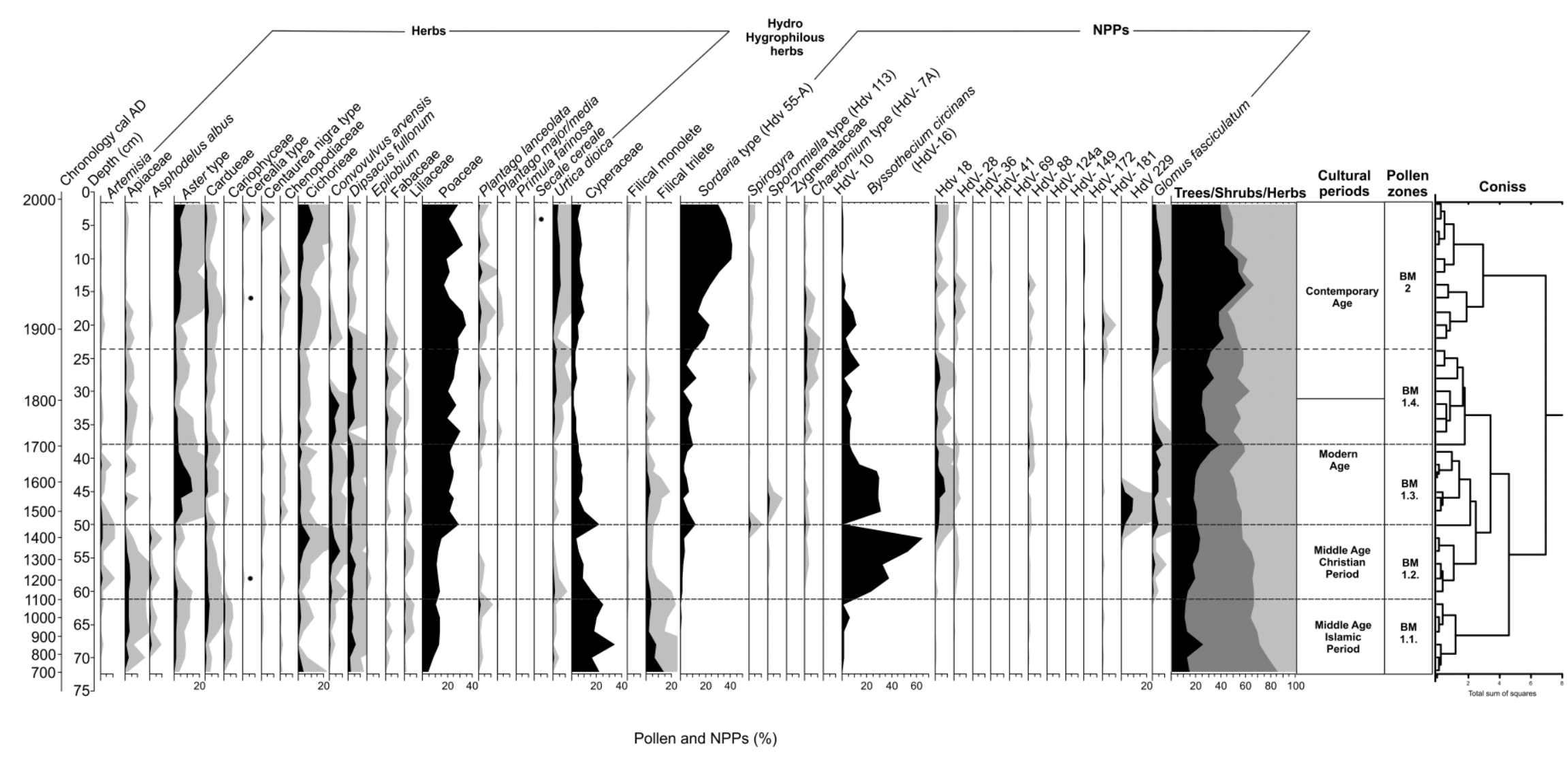

Figure 4. Bermú herbs and non-pollen palynomorphs (NPPs) diagram plotted against depth. The black silhouettes show the percentage curves of the taxa, the grey silhouettes show the $\times 5$ exaggeration curves. Dots represent percentages below $0.5 \%$. 


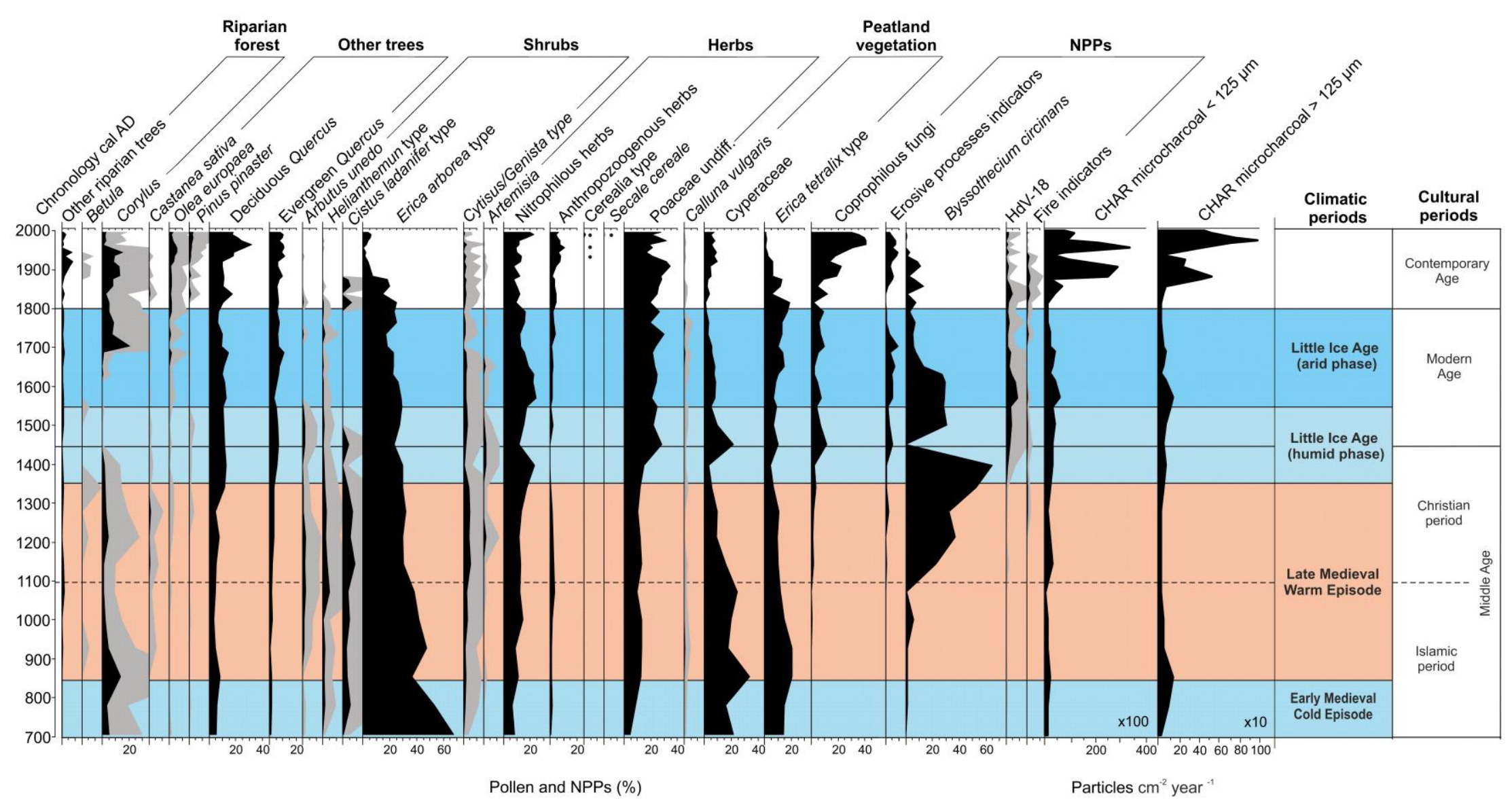

Figure 5. Synthetic Bermú mire pollen diagram plotted against age. The black silhouettes show the percentage curves of the taxa; the grey silhouettes show the $\times 5$ exaggeration curves. Dots represent percentages below 0.5\%. Other riparian trees: Alnus, Fraxinus, Populus, Salix, Ulmus. Anthropogenic-nitrophilous herbs: Aster, Asphodelus albus, Cardueae, Centaurea nigra, Cichorieae, Convovulvus arvensis, Dipsacus fullonum. Anthropozoogenous herbs: Chenopodiaceae, Plantago lanceolata, Urtica dioica. Coprophilous fungi: Sordaria (HdV-55), Sporormiella. Erosive processes indicators: Glomus, Pseudoschizaea. Fire indicators: Chaetomium (HdV-7A). 


\subsection{Islamic Period: Survival in a Warfare Land (ca. 711-1100 cal AD)}

The Bermú mire bottom is dated in the Islamic period (ca. 711-1100 cal AD), at the Early Medieval Age. By this moment (BM 1.1 pollen zone), Bermú shows an open landscape with a scarce forest cover. Riparian species such as Alnus, Fraxinus, Populus, Salix, or Ulmus among others are also extended around Bermú mire. Despite the regular tendency shown by trees, at middle $19^{\text {th }}$ century cal AD, there was a decrease of deciduous oaks and a reduction of Corylus avellana percentages, highlighting the end of a cold and humid phase, also indicated by the descending levels of Cyperaceae. At the same time, Castanea sativa appears with low percentages (1.1\%). This taxon is not widely spread along the Toledo Mountains, but it was also found in Patateros record at this time [29] (Figures 1 and 6). This landscape stems from the human communities development in the area, and endures over the whole Islamic period.

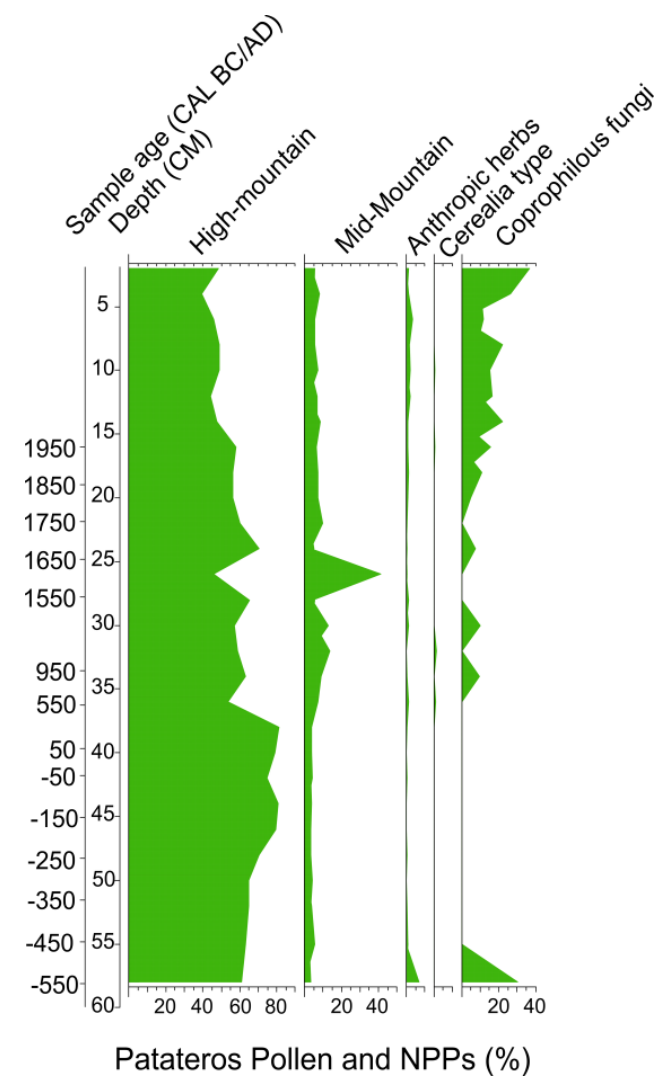

Figure 6. Patateros mire synthetic diagram. High-mountain species: Pinus pinaster, Pinus sylvestris, Calluna vulgaris, Erica spp. Cytisus type. Mid-mountain species: Deciduous Quercus, evergreen Quercus, Castanea sativa, Olea europaea, Cistus ladanifer. Anthropic herbs: Aster, Asphodelus albus, Cardueae, Centaurea nigra, Cichorieae, Convolvulus arvensis, Dipsacus fullonum. Coprophilous fungi: Sordaria (HdV-55), Sporormiella.

This scarce forest cover, which is a consequence of a disturbed landscape, led a wide brushwood line. Erica is the most representative element in this landscape, according to the results showed in every single place studied until this moment. E. tetralix $(20.5 \%)$ is the main species associated to the mire environment. By this reason, it was excluded from the pollen sum, and it is present in all of the studied places $[29,30,59,60]$. Cistus ladanifer (6.3\%), Cytisus / Genista type (3.7\%), and Helianthemum type (5.6\%), as well as Calluna vulgaris ( $0.9 \%$ ) or Arbutus unedo (2.5\%), cover the wide open space under the canopy, as they also do in places such as the nearby Valdeyernos or La Botija $[29,30,61]$ (Figure 1, Figure 7, and Figure 8). 


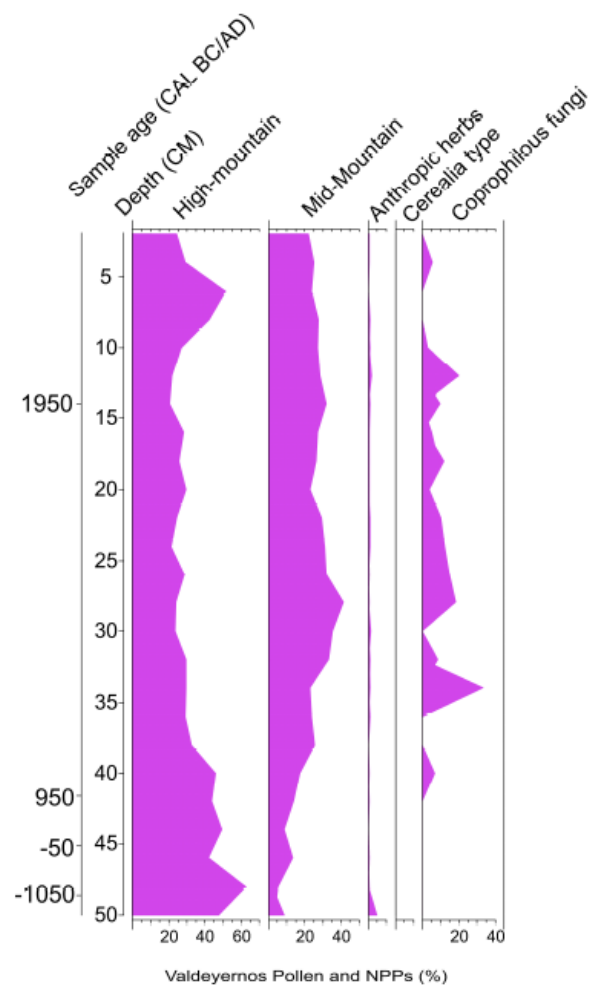

Figure 7. Valdeyernos mire synthetic diagram. High-mountain species: Pinus pinaster, Pinus sylvestris, Calluna vulgaris, Erica spp. Cytisus type. Mid-mountain species: Deciduous Quercus, evergreen Quercus, Castanea sativa, Olea europaea, Cistus ladanifer.

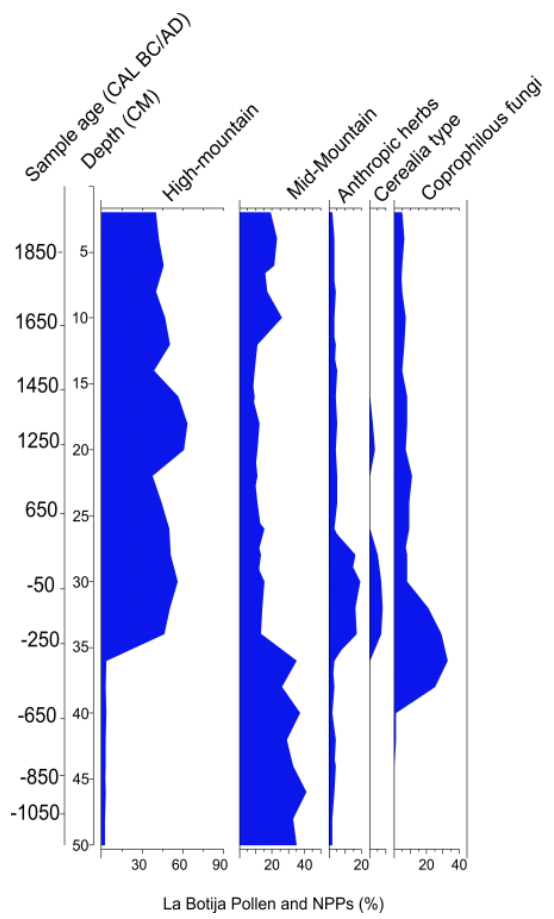

Figure 8. La Botija mire synthetic diagram. High-mountain species: Pinus pinaster, Pinus sylvestris, Calluna vulgaris, Erica spp. Cytisus type. Mid-mountain species: Deciduous Quercus, evergreen Quercus, Castanea sativa, Olea europaea, Cistus ladanifer. 
The herbaceous layer is mainly composed by Poaceae (13.4\%) and anthropogenic nitrophilous herbs pollen taxa (Aster, Cardueae, Cichorieae, Centaurea nigra, Asphodelus albus, Convolvulus arvensis or Dipsacus fullonum). These are indicators of human activities next to the mire, and are probably related to the use of many routes crossing close to the study site, although no cereal, legume pollen, nor anthropozoogenic taxa have been found in this pollen zone. A local fire occurred during the eigth century cal AD, when CHAR microcharcoal $>125 \mu \mathrm{m}$ registered a peak (138 particles $\mathrm{cm}^{-2}$ year $^{-1}$ ), but the regional fire activity is very low, and there was not an increase of human presence in the mire surroundings.

By this time, the $\mathrm{Al}-$ Andalus northern border facing the Christian territory reached the Central System. The Toledo Mountains are part of the central Islamic district called Marca Media. During this period, the war was one of the main features of this frontier territory, which was threatened by the sporadic but constant Christian raids, more frequently as the Middle Age went on. This insecure situation is also linked to many internal troubles of the Islamic kingdom, making a safe development difficult [62,63]. The population living there was scarce; it was composed of basically mozarabs - Christians living in Islamic territory-because, as Ladero-Quesada [64] and Boloix-Gallardo [63] remarked, the Arabic and bereber immigration was scarce till these northern domains. So, in the end, we cannot assure a very intense exploitation of the mire in the Islamic period.

The economy was characterized by agriculture in the lowlands, and livestock prospered in the mountainous lands [65-68]. The mid-mountain areas were more used for grazing pasturelands than for agricultural practices, as the absence of cereal pollen grains and the presence of pastureland indicators mark, although they did not focus around Bermú (Figure 5). Islamic society divided the rural space in alquerías, or territories belonging to many small farms. These little farms managed the wide space that was available, drawing a scattered population pattern, and made grazing as its economic code, which fit perfectly into the warfare and a not very populated context $[69,70]$. Transhumance was practiced covering short distances, and it is interesting to remark on the main role played by the secondary products such as leather and wood. Muslims introduced the Merino race, which will become essential on Castilian economy, but which did not play a main role over the landscape by this time [69-71]. The Coprophilous fungi (Sordaria sp.) found at this pollen zone were very scarce $(0.5 \%)$, and the levels of grazing indicators were also too low to assess human exploitation of the Bermú surroundings, as also happens at Valdeyernos (Figure 7). On the contrary, La Botija and Patateros (Figures 6 and 8) show higher coprophilous fungi values, which are likely related to an increasing livestock pressure, especially at the end of the period, when cereal type pollen is recorded in La Botija (Figure 8) [29,30,61].

Cyperaceae $(24.9 \%)$ and Filicales trilete spores (14.2\%) highlight the climatic conditions-mainly cold and humid—which define the Early Medieval Cold Episode (ca. 450-950 cal AD) [20].

\subsection{Christian Period: Building a New Order (ca. 1110-1450 cal AD)}

The pollen diagram of Bermú still shows a scant forest cover (23.7\%), although some transformations are noticeable (bottom of BM 1.2 pollen zone), such as the increase of both deciduous and evergreen oaks (12.7\% and 7.3\%\%, respectively) since the eighth century cal AD (Figures 3-5), except for a scant descent in the second half of the eighth century (1278 cal AD). The same dynamic is found in the other studied sites, such as Patateros and Valdeyernos. It is also interesting to note the significant Castanea sativa pollen percentages (2.1\%), in contrast to Patateros, which shows a soft decreasing trend at the end of this period. Human management could be tracked in these growths, but they could have been also favored by the more humid conditions present during the Late Medieval Warm Episode [72,73]. Pinus type pollen is lower than in previous steps $(1.2 \%)$, and Corylus avellana keeps the average percentages, despite a tiny descending trend. The opposite situation is found in the nearby Valdeyernos or La Botija, but is similar to Patateros mire (Figure 8).

Brush layer (53.4\%) is mainly composed by Erica in Bermú, which is similar to in the other analyzed mires. In this study site, total brush pollen values diminished (top of BM 1.2 pollen zone), especially in the end of $14^{\text {th }}$ century (1339-1397 cal AD, 42.8-34\%). This reduction fits with the 
increasing trend shown by the trees layer. This reduction is also noticeable in western placements such as La Botija, but not in Patateros mire, where the end of this period includes an increase of Erica type. The other taxa remained low, with a reduction in their pollen concentration since the $15^{\text {th }}$ century cal AD. This tendency is especially clear in Cistus ladanifer (9.7-0.7\%). In Valdeyernos, the total shrub layer tends to increase by the end of the period.

The Poaceae pastureland increased, while the above-mentioned high percentages of coprophilous fungi and the absence of cereal pollen point out the presence of livestock in the mire's surroundings (Figures 5 and 7).

Furthermore, there is also an increase of erosion indicators (e.g., Glomus (5.3\%) in Bermú and in Valdeyernos pollen records (Figures 5-8), which may indicate the mentioned loss of tree cover. It is interesting to highlight that all those processes came accompanied by a soft increase in CHAR trends, especially by the end of the period. CHAR microcharcoal $>125 \mu \mathrm{m}$ reached 71.94 particles $\mathrm{cm}^{-2}$ year $^{-1}$, and regional fire indicators were also higher than at the beginning of the Christian conquer (CHAR microcharcoal $<125 \mu \mathrm{m} 3735.97$ particles $\mathrm{cm}^{-2}$ year $^{-1}$ ).

The Christian period is a warfare time as well, especially in the first centuries [74,75]. Repopulation, as a mechanism to stabilize the Castilian presence, became a royal task, whose pace and advance was directly linked to internal al-Andalus conflicts [76]. Thus, repopulation was not well established until the $14^{\text {th }}$ century, as reflected by the increase of anthropogenic indicators and the tree cover drop (Figures 5 and 8). Repopulation implies land ownership change, triggering the property concentration mainly by Toledo's Cathedral and the Crown. An interesting episode involving the study site is the sale of Toledo Mountains land, including the castles and fortifications, made by Fernando III to the Toledo Council in 1246 AD. However, there is not a very noticeable impact over the surrounding Bermú landscape after that. The territory was disperse and composed by not very numerous little towns depending on the city; this structure guaranteed Toledo's supply, obtaining among others wood, hunting, and two very highly estimated products: honey and wax [75-77].

Transhumance movements, which were present in a low scale due to the Islamic tradition, were favored after Toledo surrender in 1085, but especially after the eighth century, when the Christian border was finally fixed south enough to keep these lands safe. The new inhabitants could connect the Cuenca range and western Tagus river lands as summer and winter grazing pasturelands, respectively, where open woodland landscape was prepared once again for the cattle supply [76,78]. Grazing practices had a parallel development with the repopulation movements as shown in the diagrams (Figures 3-8). Livestock in this area begins with local flocks associated with the neighborhoods and reached its maximum when the La Mesta Council was founded in the eighth century $[67,79]$. New pastureland was necessary, which was a facility along with the tax exemptions that constituted a lure for new inhabitants [78]. Since this moment, the La Mesta Council extended, protected, and regulated livestock movements. Many paths or Cañadas crossed close to these mountains, such as Cañada Real Leonesa and Cañada Real Segoviana, connecting with the northern grazing lands of the Central System, or Cañada Real Manchega, which were bound for Murcia and Andalucía. The Toledo Mountains were one of those extreme lands used for grazing during the summertime.

The Christian period is climatically defined by the Late Medieval Warm Episode (ca. 900-1300 cal AD) [72,73], with higher temperatures and drier conditions in the northwest hemisphere. By the beginning of this moment, the amount of humid indicators is scarce: (i) HdV-18 percentages are almost absent (0.2-1.4\%), and (ii) Cyperaceae or fern spores display a descending trend. However, this temperature rising joins the increasing human environment exploitation, which has a direct consequence on Bermú nature: the mire suffers an eutrophication process reflected in the great growth of Byssothecium circinans (HdV-16) (64.6\%). The Little Ice Age (ca. 1350-1850 cal AD) starts at the end of Middle Age [20]. Temperatures descend [80,81] and humid indicators rise not only in Bermú $(3.3 \%)$, but also in Valdeyernos or La Botija mire [30,61], while the presence of HdV-16 is lower, in part due to the increasing rainfall in the first Little Ice Age humid phase (ca. 1300-1570 cal AD) [81]. 


\subsection{Modern Age Period: Grazing Shaping the Landscape (ca. 1450-1800 cal AD)}

Along the Modern Age period (BM 1.3 and bottom of BM 1.4 pollen zones), the forest canopy shows a modest recovery trend (39.7\%). Olea europaea reappears $(2.7 \%)$, and there is no evidence of Castanea sativa during this period. The main genus is still Quercus, especially deciduous oaks (14.6\%) such as in Valdeyernos, while Pinus pollen maintains very low percentages $(2 \%)$. In the western border of the Toledo Mountains the trend is opposite, except for Las Lanchas mire, where the amount of evergreen and deciduous oaks is similar, and there is also a remarkable Quercus suber population. This duality between east and west is also perceptible in relation to Corylus avellana development. There is an abrupt reappearance of this species in Bermú at the end of the $17^{\text {th }}$ century cal AD (1686-1703 cal $\mathrm{AD}$, from $1.8 \%$ to $22 \%$; top of $\mathrm{BM} 1.3$ pollen zone), reaching its highest peak in the sequence, as it also happened in Valdeyernos, with an opposite trend at the western side of the Toledo Mountains, as shown in La Botija, and by its absence in Las Lanchas and Patateros [29,30,59,61]. However, the Corylus population diminished and stabilized in Bermú at the end of this period (6.1\%) when the oaks recovered.

This modest tree recovery triggered a soft brushwood reduction (36.2-26.6\%), specifically of Erica, while many taxa such as Cistus ladanifer, Arbutus unedo, and Prunus disappeared. Poaceae is the main herbaceous type at this period, maintaining the previous period levels with a little increasing trend. Nevertheless, it is necessary to mention the great amount of anthropogenic indicators: (i) nitrophilous herbs (Aster, Asphodelus albus, Cardueae, Centaurea nigra, Cichorieae, Convovulvus arvensis, Dipsacus fullonum) (33.1\%); (ii) anthropozoogenous herbs (Chenopodiaceae, Plantago lanceolata, Urtica dioica) $(3.8 \%)$, especially after the $18^{\text {th }}$ century cal $\mathrm{AD}$; and (iii) high coprophilous fungi values $(9.6 \%)$, highlighting the impact of grazing activities (Figures 3-5). Due to the lack of pasturelands and crop fields, the Toledo Council allowed the neighbors to use forest resources, generating new open spaces. This spread is indicated in the Bermú pollen diagram with the pastureland increasing $[73,82]$. The big amount of erosion indicators (9.2\%) confirms this new forest exploitation. However, fire is not the most used tool; CHAR show a descending trend: CHAR microcharcoal $>125 \mu \mathrm{m}$ decreased to 4.69 particles $\mathrm{cm}^{-2}$ year $^{-1}$, and CHAR microcharcoal $<125 \mu \mathrm{m}$ decreased to ca. 364.83 particles $\mathrm{cm}^{-2}$ year $^{-1}$.

A change in the land use began in the $17^{\text {th }}$ century. Due to the subsistence crisis happening during those years, many royal properties were sold, changing their traditional use. Forest lands were specially affected, despite the forestall conservation trials applied [83]. In fact, woodland use with livestock purposes was at this moment so intense that the Toledo Council prohibited the felling and promoted the first forest repopulations; they were also focused on trying to avoid fire episodes, forbidding the flocks from getting into burned pastureland $[75,82,83]$. Fire is not just a tool anymore, but rather a threat for forest resources. The Modern Age is the period when important conservation policies are promoted, especially during the $14^{\text {th }}$ and $15^{\text {th }}$ centuries [83]. Lots of these rules were focused on fire, such as those establishing fire calendars excluding the warmest months or the obligation to intervene when someone detected a fire. Since then, stockbreeder interests were protected, and wood or charcoal use was regulated. All of those rules were actualized at the beginning of the $16^{\text {th }}$ century, when deforestation became more evident in the whole kingdom [75].

During this period, it is necessary to focus on the La Mesta Council's movements. By the Modern Age, this organization is powerful enough to dominate the main flocks in the whole country. The owners built a large and solid net to manage these livestock movements along the cattle roads [27]. This has a noteworthy impact over the landscape configuration, as it points out the high presence of oaks and Poaceae pastureland in many studied sites, building an open woodland landscape that meets human necessities.

During the Modern Age, the climate is determined by the Little Ice Age (ca. 1300-1850 cal AD) [84]. In the first years, the humid phase maintained rainy and cold conditions, but it was mainly the arid phase (ca. 1570-1800 cal AD) that marked this cultural time [72,81]. In Bermú record, it is possible to appreciate the growth of HdV-18 at the beginning of this period, but at the end, it descends alongside Cyperaceae, which falls during the whole phase. Many drought and floods episodes periodically 
affected the area during the $17^{\text {th }}$ century [84]. These episodes are very noticeable in the little amount of humid indicators and the second eutrophization process that suffered by the studied mire, which was pointed out by the great percentages of HdV-16 (30.8\%) (Figure 5).

\subsection{Contemporary Age Period: a Changing Tendency (ca. 1800 cal AD-Present)}

By this time (top of BM 1.4 and BM 2 pollen zones), the trend in Bermú is a progressive forest recovery (arboreal pollen percentages increased 25.8-60.7\%, see Figure 3), while in the nearby Valdeyernos, there is a better equilibrium between trees, shrubs, and herbs. Westwards, only Las Lanchas was characterized by a higher tree cover, while the other two study sites, marked by a livestock economy, presented an open landscape [61]. In Bermú, the main forest elements remained deciduous oaks (10.4-31.8\%) followed by evergreen oaks (6.9-11.7\%), composing a wide mixed forest that replaced the shrub layer, although Poacaeae pastureland was still dominant.

The riparian forest reappeared in the second half of the century, and it was more present at the river banks. Pinus species, and more specifically Pinus pinaster $(3.6 \%)$, were widely used in the repopulations that developed during the $20^{\text {th }}$ century. These additions are perfectly recognizable in Bermú record and also in Patateros, where it is the main tree layer component. Diagrams show that the recent landscape has been shaped by the laws and initiatives that were trying to recover the forest throughout the whole country. They were especially intense from 1940 to 1970, when many afforestation programmes were carried out on public and private lands. In the Toledo Mountains, these plans respected the original species such as Pyrenean oak and holm oak, as the pollen diagram displays. The main introduced species in this area were pines, which quickly invaded the abandoned agricultural fields, generating second-generation forests $[9,85,86]$.

Corylus avellana also had a great role in Bermú, where it was present since the first half of this period. Among the cultivated species, it is interesting to highlight the importance gained by Olea europaea at this time (1.9-6.6\%), getting prominence in the area alongside the Castanea sativa slight reintroduction $(1.2 \%)$, which disappeared at the beginning of the $20^{\text {th }}$ century (BM 2 pollen zone). Olea europaea is not very relevant in Valdeyernos. It is possible that the pollen recorded there came from the Bermú surrounds. At the western side, only La Botija recorded a great amount of Olea europaea but very low percentages of Castanea sativa, which is also present in Patateros or Las Lanchas, but absent in Valdeyernos $[29,30,60,61]$.

On the other hand, a decreasing trend is found in the brushwood layer, which was $38.3 \%$ at the beginning of the period at $1800 \mathrm{cal} \mathrm{AD}$, and $7.4 \%$ at the end of $19^{\text {th }}$ century (top of BM 1.4 pollen zone), and only $5.9 \%$ at the top of the pollen record (BM 2 pollen zone). This change is especially noticeable in Ericaceace, except in the nearby Valdeyernos, where a big increase is shown. Cistus ladanifer disappeared as well as Erica type at the beginning of the $19^{\text {th }}$ century, while Prunus began to increase $(3 \%)$, similar to in Valdeyernos. On the contrary, at the western edge, Erica type was the main species composing the brush layer. In Las Lanchas, it tended to grow despite the soft decreasing tendency found in many places such as Patateros $[29,30,60,61]$.

Herbs (36-54.2\%) were mainly still composed by Poaceae and nitrophilous herbs, but with a major presence of anthropozoogenic herbs $(6.0 \%)$, especially since the beginning of the $20^{\text {th }}$ century cal AD. Human presence at Bermú is very clear, which is also indicated by the appearance at this moment of cereal pollen in the record. There is not enough pollen to confirm its cultivation in the mire edge (only $0.2-1.2 \%$ ), but it reveals its cultivation in the area, particularly during the last decades of the $20^{\text {th }}$ century cal AD. On the contrary, in Las Lanchas, where cereal pollen reached a great amount during the Modern Age, this type is absent during the Contemporary Age (Figures 5 and 9). On the western side, in Patateros, and in Valdeyernos, the cereal pollen concentration was also very low (Figures 6 and 7). 


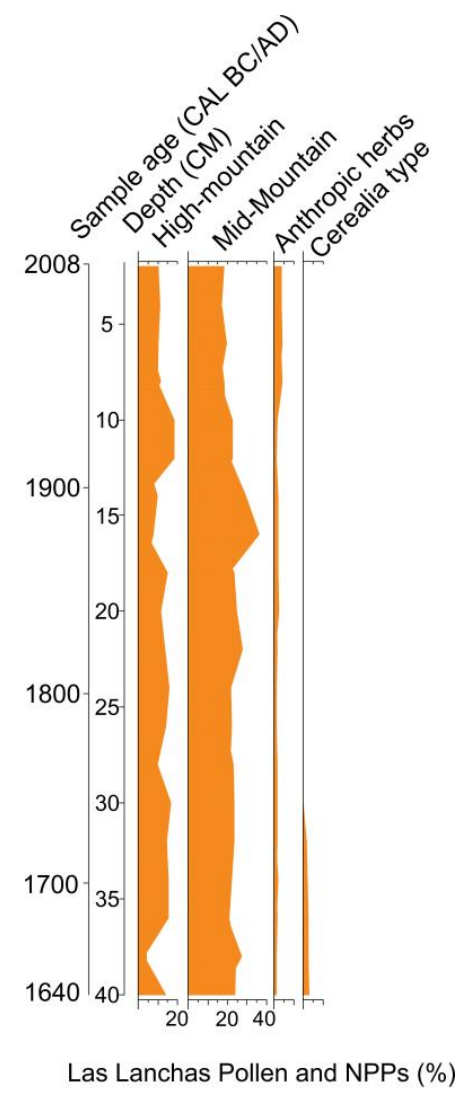

Figure 9. Las Lanchas mire synthetic diagram. High-mountain species: Pinus pinaster, Pinus sylvestris, and Calluna vulgaris, Erica spp. Cytisus type. Mid-mountain species: Deciduous Quercus, evergreen Quercus, Castanea sativa, Olea europaea, and Cistus ladanifer.

There is an evident increase in erosion indicators (2.4\%) despite the forest recovery, which points to a major land use by humans and higher pressure on it. The CHAR trend in Bermú showed two peaks: $1883 \mathrm{cal}$ AD presents values ca. $25,077.77 \mathrm{~cm}^{-2}$ year ${ }^{-1}$, which increased to $28,789.99 \mathrm{~cm}^{-2}$ year ${ }^{-1}$ in $1908 \mathrm{cal} \mathrm{AD}$, showing a noticeable regional fire activity. On the other hand, the local fires also had an intense impact over the landscape close to Bermú mire, despite the descending tendency of CHAR microcharcoal $<125 \mu \mathrm{m}$ (1883 cal AD values ca. $520.79 \mathrm{~cm}^{-2}$ year $^{-1}$ and $1908 \mathrm{cal}$ AD values ca. $230.07 \mathrm{~cm}^{-2}$ year $\left.^{-1}\right)$. These charcoal peaks came along with evidence of fire indicators $(2.4 \%)$, although they were scarce and almost absent at the end of the period. During the $20^{\text {th }}$ century cal AD, CHAR presented their maximum values (CHAR microcharcoal $<125 \mu \mathrm{m} 33,074.97 \mathrm{~cm}^{-2}$ year $^{-1}$ and CHAR microcharcoal $>125 \mu \mathrm{m} 968.93 \mathrm{~cm}^{-2}$ year $^{-1}$ ).

The first local fire episode could be associated with livestock because it occured simultaneously with an increase of coprophilous fungi and anthropozoogenic herbs. It's very interesting to highlight here the abrupt stop of fire indicators at the same time that the Pinus species are reintroduced, following the reforestation policies. This new fire management is not recorded in the studied mires on the western side, so we could associate the second peak to an extra local fire or a very located event not affecting vegetation dynamics around Bermú. Byssothecium circinans (HdV-16) doesn't show great values (its maximum is $13.8 \%$ ), but rather an irregular trend that could also point out the use made by the human communities of this space.

During this period, the population behaves according to two different trends, which produce two tendencies over the landscape as well. During the $19^{\text {th }}$ century, the population kept increasing in the area, whereas in the $20^{\text {th }}$ century, there was a great movement from the rural areas to the cities, leaving the former with a very low population density. Therefore, during the first part of the period, 
the resources demand was higher, and agriculture spread its limits throughout these mountains, using low-quality and distant lands [26]. During the second half of this period, due to the lack of workforce, previously forced lands were abandoned and recovered back to forest $[9,26,87]$.

The most important action performed in the Toledo Mountains during the Contemporary Age, affecting the whole country, were the Confiscation Laws. These laws were accomplished during the $19^{\text {th }}$ century and triggered a land owning change with evident consequences for the forest all over the country [83]. The first disentailment event was performed in 1837, and especially affected the Church properties $[83,85,88,89]$. Madoz's disentailment was ordered in 1855 . In this case, it tried to exclude mountainous lands from the sale with a relative success. In 1868, the Treasury also sold the State Mountains if they didn't have a particular ecological value $[88,89]$. In the Toledo Mountains, the public lands were divided up between the neighbors, ending the monopoly held by the Toledo Council.

Agriculture was the main argument in these interventions for two reasons: (i) the population rising and (ii) Spain becoming a grain exporter during the first half of the $19^{\text {th }}$ century. This last circumstance was tied with an increase the agricultural surface area and a diversification of the products, which now included fruit trees and oil. This change can be seen in the diagram by the increase of Olea europaea percentages (Figures 3-5). Thus, $40 \%$ the Toledo Mountain's surface was catalogued as able to be ploughed and sold. Even today, the consequences of this sale are present, as $60 \%$ of the Toledo Mountain territory is catalogued as a "Mountainous Agricultural Zone" [83,85,86,89].

In the Toledo Mountains, where agricultural practices were not very worthwhile because of land properties, husbandry became necessary, as it has been pointed out before. However, the La Mesta Council disappeared in 1836 when transhumance dynamics were reduced. The main reasons were the drop in the number of transhumant livestock, the appearance of new grazing models, such as the stabled cattle, and the lost of importance of the Spanish wood in the international markets $[83,87,90]$. These changes are perceptible on the Bermú pollen diagram (Figures 3-5). Trees increased and shrubs suffered an evident drop, while the coprophilous fungi concentration grew as a result of the bigger exploitation of the mire. Alongside livestock, hunting was the main economic activity performed in the Toledo Mountains, which means that Bermú itself was placed within an area designated for this activity. Deer became the more widespread species in the whole shire. Also, many vegetal taxa were affected by the uses that these animals made of them for feeding or cleaning procedures, such as the horn scrub against the trunk or branches. In fact, many studies have been conducted in order to determine the damage that the heath species suffered. One of them made precisely inside the Los Quintos de Mora property [91] claimed that the preference shown by this ungulate for the arbutus (Arbutus unedo), rockrose (Cistus ladanifer), or false olive (Phillyrea angustifolia) was perceptible in the Bermú pollen diagram (Figure 3) [91,92].

Along with the increasingly important role played by hunting, it is possible to trace the traditional activities supporting population, which are now shown with more intensity. Among them, one of the most important resources was wood charcoal, which people used as the main fuel until the mineral charcoal appeared [93]. Heather charcoal was much appreciated, alongside holm oak and other shrubs. The drop of Erica sp. and the fluctuating trend of evergreen oaks are good reflections of this trend. This activity was fiercely regulated in the Toledo Mountains, but it was not always made under license or legal conditions $[7,75]$. Nevertheless, this activity decreased by the second half of the $20^{\text {th }}$ century when the population migrated to the cities, reducing considerably its demand on the territory and the use of these fuels.

This period seems to be arid, as shown by the absence of fern spores and the low levels of HdV-18 (4.6\% maximum); similar Figures were also recorded in the other study sites except in Valdeyernos, where there was an intense increase of this NPP as well as in Las Lanchas, which was likely linked to their humid natural conditions. 


\section{Conclusions}

The Toledo Mountains' landscape is the consequence of the effect of the climatic dynamic and the human land use through time. As a mid-mountain ecosystem, the possibilities offered to the human communities were so wide due to the wide variety in resources and mild climate. These particular circumstances allowed the inhabitants to develop different activities in order to make the most of the means. Bermú mire interdisciplinary paleoecological study is a long-term pollen-based research. These kinds of studies provide a long-term perspective of all those climatic and anthropic synchronous changes unleashing landscape transformations $[13,14,94]$. In this case, it shows an environment shaped by the human communities through time with a dynamic that is very similar to the other study sites near this land $[29,30,60,61]$. By the Islamic period (711-1100 cal AD), the area was dominated by an open landscape, although the trending change was produced in the Late Iron Age, as shown in other study sites.

Despite the low agricultural quality, the Toledo Mountains' landscape was intensely used in many ways, especially after the Christian conquer and repopulation movements. Grazing, hunting, and forest exploitation were the most important activities performed in these lands, which generated open landscapes and pastureland for the cattle support in a way that is still present even today.

The cultural landscape that has been built over time in the Toledo Mountains is narrowly linked to human development. Political settings and different socio-economic trends forced human communities to either put higher pressure on the landscape and sometimes promote forest restoration; both of these trends reflect the main role played by the wood business during the Middle and Modern Age. The demographic trends sometimes generated a higher pressure as when the repopulation movements succeeded in the Late Middle Age or moved the tendency toward a softer interaction, as happened in the Contemporary Age, when people abandoned the rural areas and moved toward the cities. The different protection movements or reforestation attempts made on these mountains are another example of how much human beings influence their environment. Thus, it's possible to attest the main role played by humans in the Toledo Mountains, not only as a simple user but also as a builder of their own reflexion in the environment.

Author Contributions: Conceptualization, R.L.-L., S.P.-D. and J.A.L.-S.; Data curation, S.P.-D. and J.A.L.-S.; Formal analysis, R.L.-L., S.P.-D. and F.A.-S.; Funding acquisition, J.A.L.-S.; Investigation, R.L.-L., S.P.-D. and J.A.L.-S.; Methodology, J.A.L.-S.; Project administration, J.A.L.-S.; Resources, S.P.-D.; Supervision, S.P.-D. and J.A.L.-S.; Validation, S.P.-D. and J.A.L.-S.; Writing—original draft, R.L.-L.; Writing-review and editing, S.P.-D., F.A.-S., D.A.-S. and J.A.L.-S.

Funding: This research was funded the project REDISCO-HAR2017-88035-P (Plan Nacional I+D+I, Spanish Ministry of Economy and Competitiveness). Reyes Luelmo is funded by a FPU grant (Spanish Ministry of Education, Culture and Sports).

Acknowledgments: This publication was funded by the Laboratorio di Palinologia e Paleobotanica-CEA 2018 Award for the oral presentation titled 'A mid-mountain landscape shaped during fourteen centuries in the heart of Toledo Mountains (central Iberia): the Bermú peat bog record' by Luelmo-Lautenschlaeger Reyes, López-Sáez José-Antonio and Pérez-Díaz Sebastián presented at XIVth Confererence of Environmental Archaeology.

Conflicts of Interest: The authors declare no conflicts of interest.

\section{References}

1. Galop, D. La Forêt, L'homme et le Troupeau Dans les Pyrénées. 6000 ans D'histoire de L'environnement Entre Garonne et Méditerranée; Geode: Toulouse, France, 1998; 285p, ISBN 9782912025012.

2. Lozny, L.R. Continuity and Change in Cultural Adaptation to Mountain Environments: From Prehistory to Comtemporary Threats; Springer: New York, NY, USA, 2013; 410p, ISBN 978146145702.

3. Pérez-Díaz, S.; Núñez de la Fuente, S.; Frochoso Sánchez, M.; González Pellejero, R.; Allende Álvarez, F.; López-Sáez, J.A. Seis mil años de gestión y dinámica antrópica en el entorno del Parque Natural de los Collados del Asón (Cordillera Cantábrica Oriental). Cuaternario y Geomorfología 2016, 30, 49-74. [CrossRef] 
4. Robles-López, S.; Luelmo-Lautenschlaeger, R.; Pérez-Díaz, S.; Abel-Schaad, D.; Alba-Sánchez, F.; Ruiz-Alonso, M.; López-Sáez, J.A. Vulnerabilidad y resiliencia de los pinares de alta montaña de la Sierra de Gredos (Ávila, Sistema Central): Dos mil años de dinámica socioecológica. Cuaternario y Geomorfología 2017, 31, 51-72. [CrossRef]

5. Mirás, Y.; Ejarque, A.; Orengo, H.; Mora, S.R.; Palet, J.M.; Poiraud, A. Prehistoric impact on landscape and vegetation at high altitudes: An integrated palaeoecological and archaeological approach in the Eastern Pyrenees (Perafita valley, Andorra). Plant Biosyst. 2010, 144, 924-939. [CrossRef]

6. Pérez-Obiol, R.; Jalut, G.; Julià, R.; Pèlachs, A.; Iriarte, M.J.; Otto, T.; Hernández-Beloqui, B. Mid-Holocene vegetation and climatic history of the Iberian Peninsula. Holocene 2011, 21, 75-93. [CrossRef]

7. Vanwalleghem, T.; Gómez, J.A.; Infante-Amate, J.; González-de Molina, M.; Vanderlinden, K.; Guzmán, G.; Laguna, A.; Giráldez, J.V. Impact of historical land use and soil management change on soil erosion and agricultural sustainability during the Antropocene. Anthropocene 2017, 17, 13-29. [CrossRef]

8. Pausas, J.G.; Keeley, J.E. A burning story: The role of fire in the history of life. BioScience 2009, 59, 593-601. [CrossRef]

9. Bebi, P.; Seidl, R.; Motta, R.; Fuhr, M.; Firm, D.; Krumm, F.; Conedera, M.; Ginzler, C.; Wohlgemuth, T.; Kulakowski, D. Changes of forest cover and disturbance regimes in the mountain forests of the Alps. For. Ecol. Manag. 2017, 388, 43-56. [CrossRef] [PubMed]

10. Kohler, T.; Giger, M.; Hurni, H.; Ott, C.; Wiesmann, U.; Wyman-von Dach, S.; Maselli, D. Mountains and climate change: A global concern. Mt. Res. Dev. 2010, 30, 53-55. [CrossRef]

11. López-Sáez, J.A.; Serra-González, C.; Alba-Sánchez, F.; Robles-López, S.; Pérez-Díaz, S.; Abel-Schaad, D.; Glais, A. Exploring seven hundred years of transhumance, dynamic, fire and human activity through a historical mountain pass in central Spain. J. Mt. Sci. 2016, 13, 1139-1153. [CrossRef]

12. López-Sáez, J.A.; López-Merino, L.; Alba-Sánchez, F.; Pérez-Díaz, S. Modern pollen analysis: A reliable tool for discriminating Quercus rotundifolia communities in Central Spain. Phytocoenologia 2010, 40, 57-72. [CrossRef]

13. López-Sáez, J.A.; Sánchez-Mata, D.; Alba-Sánchez, F.; Abel-Schaad, D.; Gavilán, R.G.; Pérez-Díaz, S. Discrimination of Scots pine forests in the Iberian Central System (Pinus sylvestris var. iberica) by means of pollen analysis. Phytosociological considerations. Lazaroa 2013, 34, 191-208. [CrossRef]

14. López-Sáez, J.A.; Alba-Sánchez, F.; Sánchez-Mata, D.; Abel-Schaad, D.; Gavilán, R.G.; Pérez-Díaz, S. A palynological approach to the study of Quercus pyrenaica forest communities in the Spanish Central System. Phytocoenologia 2015, 45, 107-124. [CrossRef]

15. Mercuri, A.M. Applied palynology as a trans-disciplinary science: The contribution of aerobiology data to forensic and palaeoenvironmental issues. Aerobiología 2015, 31, 323-339. [CrossRef]

16. Pérez-Sanz, A.; González-Sampériz, P.; Moreno, A.; Valero-Garcés, B.; Gil-Romerá, G.; Rieradevall, M.; Tarrats, P.; Lasheras-Álvarez, L.; Morellón, M.; Belmonte, A.; Sancho, C. Holocene climate variability, vegetation dynamics and fire regime in the central Pyrenees: The Basa de la Mora sequence (NE Spain). Quat. Sci. Rev. 2013, 73, 149-169. [CrossRef]

17. Valero-Garcés, B.L.; Moreno, A.; González-Sampériz, P.; Morellón, M.; Rico, M.; Corella, J.P.; Jiménez-Sánchez, M.; Domínguez-Cuesta, M.J.; Farias, P.; Stoll, H.; et al. Evolución climática y ambiental del Parque Nacional de Picos de Europa desde el último máximo glaciar. In Proyectos de Investigación en Parques Nacionales: 2006-2009; Organismo Autónomo de Parques Nacionales (España): Madrid, Spain, 2010; pp. 55-71. ISBN 9788480147224.

18. Ruiz-Fernández, J.; Oliva, M.; Cruces, A.; López, V.; da Conceiçao-Freitas, M.; Andrade, C.; García Hernández, C.; López-Sáez, J.A.; Geraldes, M. Environmental evolution in the Picos de Europa (Cantabrian Mountains, SW Europe) since the Last Glaciation. Quat. Sci. Rev. 2016, 138, 87-104. [CrossRef]

19. Franco-Múgica, F.; García-Antón, M.; Sainz-Ollero, H. Impacto antrópico y dinámica de la vegetación durante los últimos 2000 años BP en la vertiente septentrional de la Sierra de Gredos: Navarredonda (Ávila, España). Revue de Paleobiología 1997, 16, 29-45.

20. López-Sáez, J.A.; Abel-Schaad, D.; Pérez-Díaz, S.; Blanco-González, A.; Alba-Sánchez, F.; Dorado, M.; Ruiz-Zapata, B.; Gil-García, M.J.; Gómez-González, C.; Franco-Múgica, F. Vegetation history, climate and human impact in the Spanish Central System over the last 9000 years. Quat. Int. 2014, 353, 98-122. [CrossRef]

21. Treml, V.; Jankovská, V.; Petr, L. Holocene timberline fluctuations in the mid mountains of Central Europe. Fennia 2006, 184, 107-119. 
22. Doyen, E.; Vannière, V.; Bichet, V.; Gauthier, E.; Richard, H.; Petit, C. Vegetation history and landscape management from 6500 to 1500 cal. BP at Lac d'Antre, Gallo-Roman sanctuary of Villards d'Heria, Jura, France. Veg. Hist. Archaeobot. 2011, 22, 83-97. [CrossRef]

23. Sancho-Reinoso, A. Fighting for survival. Planning and development issues in two European rural border mid-mountain regions. J. Geogr. 2010, 5, 67-81.

24. Diry, J.P. Moyennes montagnes d’Europe occidentale et dynamiques rurales. Rev. Geogr. Alp. 1955, 83, 15-26. [CrossRef]

25. Bettinger, L.; Ormaux, S. La moyene montagne européene, approche d'un concept.problème à partir de l'exemple français. Insaniyat 2011, 53, 17-39. [CrossRef]

26. Lasanta-Martínez-Martínez, T. La transformación del paisaje en montaña media por la actividad agrícola en relación con las condiciones ambientales. In Acción Humana y Desertificación en Ambientes Mediterráneos; García-Ruiz, J.M., López-García, P., Eds.; Instituto Pirenaico de Ecología: Zaragoza, Spain, 1997; pp. 145-172. ISBN 9788492184224.

27. Klein, J. La Mesta: Estudio de la Historia Económica Española, 1273-1836; Alianza Editorial: Madrid, Spain, 1990; 480p, ISBN 9788420622378.

28. Molenat, J.P. Campagnes et Monts de Tolede du XIIe au XVe Siècle; Casa de Velázquez: Madrid, Spain, 1997; 724p, ISBN 9788486839789.

29. Dorado-Valiño, M.; López-Sáez, J.A.; García-Gómez, E. Patateros, Toledo Mountains (central Spain). Grana 2014, 53, 171-173. [CrossRef]

30. Dorado-Valiño, M.; López-Sáez, J.A.; García-Gómez, E. Valdeyernos, Toledo Mountains (central Spain). Grana 2014, 53, 315-317. [CrossRef]

31. López-Sáez, J.A.; García-Río, R.; Alba-Sánchez, F.; García-Gómez, E.; Pérez-Díaz, S. Peatlands in the Toledo Mountains (central Spain): Characterisation and conservation status. Mires Peat 2014, 15, 1-23.

32. Martín-Serrano, A.; Molina, E.; Nozal, F.; Carral, M.P. Itinerario A2. Transversal en los Montes de Toledo. In Itinerarios Geomorfológicos por Castilla-La Mancha: Libro de las Excursiones Desarrolladas Durante la VIII Reunión Nacional de Geomorfología, Celebrada en Toledo, 22-25 de Septiembre de 2004; Benito, G., Díez Herrero, A., Eds.; Sociedad Española de Geomorfología-CSIC Centro de Ciencias Medioambientales: Madrid, Spain, 2004; pp. 51-82. ISBN 849219586X.

33. San Miguel, A.; Rodríguez-Vigal, C.; Perea García-Calvo, R. Los Quintos de Mora. Gestión integral del monte mediterráneo. In Pastos, Paisajes Culturales Entre Tradición y Nuevos Paradigmas del Siglo XXI. Visitas de Campo; López-Carrasco, C., Rodríguez, M.P., San Miguel, A., Fernández, F., Roig, S., Eds.; Sociedad Española para el Estudio de los Pastos: Madrid, Spain, 2011; 704p, ISBN 9788461487134.

34. Perea, D.F.; Perea, R. Vegetación y Flora de los Montes de Toledo; Ediciones Covarrubias: Toledo, Spain, 2008; 296p, ISBN 9788493603519.

35. Punt, W.; Marcks, A.; Hoen, P.P. Myricaceae. Rev. Paleaeobot. Palynol. 2002, 123, 99-105. [CrossRef]

36. Sánchez-del Álamo, C.; Sardinero, S.; Bouso, V.; Hernández-Palacios, G.; Pérez-Badía, R.; Fernández-González, F. Los abedulares del Parque Nacional de Cabañeros: Sistemática, demografía, biología reproductiva y estrategias de conservación. In Proyectos de Investigación en Parques Nacionales: 2006-2009; Organismo Autónomo Parques Nacionale: Madrid, Spain, 2010; pp. 275-310.

37. Luengo-Nicolau, E.; Sánchez-Mata, D. A hazel tree relict community (Corylus avellana L., Betulaceae) from the Guadiana River Middle Basin (Ciudad Real, Spain). Lanzaroa 2015, 36, 133-137. [CrossRef]

38. Reimer, P.J.; Bard, E.; Bayliss, A.; Beck, J.W.; Blackwell, P.G.; Bronk Ramsey, C.; Buck, C.E.; Cheng, H.; Edwards, R.L.; Friedrich, M.; et al. Intcal13 and marine13 radiocarbon age calibration curves 0-50,000 years cal BP. Radiocarbon 2013, 55, 1869-1887. [CrossRef]

39. Hua, Q.; Barbetti, M. Review of tropospheric bomb ${ }^{14} \mathrm{C}$ data for carbon cycle modelling and age calibration purposes. Radiocarbon 2004, 46, 1273-1298. [CrossRef]

40. Blaauw, M. Methods and code for classical age-modelling of radiocarbon sequences. Quaternary. Geochronology 2010, 5, 512-518. [CrossRef]

41. Aaby, B.; Berglund, B.E. Characterization of peat and lake deposits. In Handbook of Holocene Palaeoecology and Palaeohydrology; Berglund, B.E., Ed.; John Wiley and Sons Ltd.: Chichester, UK, 1986; pp. 231-246. ISBN 9781930665804.

42. Moore, P.D.; Webb, J.A.; Collinson, M.E. Pollen Analysis; Blackwell: London, UK, 1991; 216p, ISBN 9780632021765. 
43. Goeury, C.; de Beaulieu, J.L. À propos de la concentration du pollen à l'aide de la liqueur de Thoulet dans les sédiments minéraux. Pollen Spores 1979, 21, 239-251.

44. Reille, M. Pollen et spores d'Europe et d'Afrique $d u$ Nord, 2nd ed.; Laboratoire de Botanique Historique et Palynologie: Marseille, France, 1999; 543p, ISBN 2950717500.

45. Van Geel, B. Non-pollen palynomorphs. In Tracking Environmental Change Using Lake Sediments, Vol. 3, Terrestrial, algal, and Siliceous Indicators; Smol, J.P., Birks, H.J.B., Last, W.M., Eds.; Kluwer: Dordrecht, The Netherlands, 2001; pp. 99-119. ISBN 9781402006814.

46. Beug, H.J. Leitfaden der Pollenbestimmung für Mittleleuropa und Angrenzende Gebeite; Gustav Fisher Verlag: Stuttgart, Germany, 2004; ISBN 9783899370430.

47. Cugny, C.; Mazier, F.; Galop, D. Modern and fossil non-pollen palynomorphs from the Basque mountains (western Pyrenees, France): The use of coprophilous fungi to reconstruct pastoral activity. Veg. Hist. Archaeobot. 2010, 19, 391-408. [CrossRef]

48. Mateus, J.E. Pollen Morphography of Portuguese Ericales. Revista Biología 1989, 14, 135-208.

49. Blackmore, S.; Steinmann, J.A.J.; Hoen, P.P.; Punt, W. Betulaceae and Corylaceae. Rev. Palaeobot. Palynol. 2003, 123, 71-98. [CrossRef]

50. Mercuri, A.M.; Bandini Mazzanti, M.; Florenzano, A.; Montecchi, M.C.; Rattighieri, E.; Torri, P. Anthropogenic Pollen Indicators (API) from archaeological sites as local evidence of human-induced environments in the italian península. Ann. Bot. Coenol. Plant Ecol. 2013, 3, 143-153. [CrossRef]

51. Stockmarr, J. Tablets with spores used in absolute pollen analysis. Pollen Spores 1971, 13, 614-621.

52. Grimm, E.D. TGView; Illinois State Museum, Research and Collection Center: Springfield, MA, USA, 2004.

53. Grimm, E.C. Coniss: A Fortran 77 program for stratigraphically constrained cluster analysis by the method of incremental sum of squares. Comput. Geosci. 1987, 13, 13-35. [CrossRef]

54. Bennett, K.D. Determination of the number of zones in a biostratigraphical sequence. New. Phytol. 1996, 132, 155-170. [CrossRef]

55. Whitlock, C.; Larsen, C. Charcoal as a fire proxy. In Tracking Environmental Change Using Lake Sediments: Volume 3. Terrestrial, Algal, and Siliceous Indicators; Smol, J.P., Birks, H.J.B., Last, W.M., Eds.; Kluwer: Dordrecht, The Netherlands, 2001; pp. 75-97. ISBN 9780306476686.

56. Vannière, B.; Colombaroli, D.; Chapron, E.; Leroux, A.; Tinner, W.; Magny, M. Climate versus human-driven fire regimes in Mediterranean landscapes: The Holocene record of Lago dell'Accesa (Tuscany, Italy). Quat. Sci. Rev. 2008, 27, 1181-1196. [CrossRef]

57. Tinner, W.; Hu, F.S. Size parameters, size-class distribution and area-number relationship of microscopic charcoal: Relevance for fire reconstruction. Holocene 2003, 13, 499-505. [CrossRef]

58. Long, C.J.; Whitlock, C. Fire and vegetation history from the coastal rain forest of the Western Oregon Coast Range. Quat. Res. 2002, 58, 215-225. [CrossRef]

59. Carcaillet, C.; Bouvier, M.; Fréchette, B.; Larouche, A.C.; Richard, P.J.H. Comparison of pollen-slice and sieving methods in lacustrine charcoal analyses for local and regional fire history. Holocene 2001, 11, 467-476. [CrossRef]

60. Luelmo-Lautenschlaeger, R.; López-Sáez, J.A.; Pérez-Díaz, S. Las Lanchas, Toledo Mountains (central Spain). Grana 2018, 57, 246-248. [CrossRef]

61. Luelmo-Lautenschlaeger, R.; López-Sáez, J.A.; Pérez-Díaz, S. Botija, Toledo Mountains (central Spain). Grana 2018, 57, 322-324. [CrossRef]

62. Herrera-Casado, A. La Marca media de Al-Andalus en tierras de Guadalajara. Wad-al-Hayara 1985, 12, 9-26.

63. Boloix-Gallardo, B. La taifa de Toledo en el Siglo XI. Aproximación a sus límites y extensión territorial. Tulaytula 2001, 8, 23-57.

64. Ladero-Quesada, M.A. Toledo en Época de la Frontera; Anales de la Universidad de Alicante. Historia Medieval; Universidad de Alicante: Alicante, Spain, 1984; Volume 3, pp. 71-88.

65. Blanco-González, A.; López-Sáez, J.A.; López-Merino, L. Ocupación y uso del territorio en el sector centromeridional de la cuenca del Duero entre la Antigüedad y la Alta Edad Media (siglos I-XI d.C.). Archivo Español de Arqueología 2009, 82, 275-300. [CrossRef]

66. Blanco-González, A.; López-Sáez, J.A.; Alba, F.; Abel-Schaad, D.; Pérez-Díaz, S. Medieval landscapes in the Spanish Central System (450-1350): A palaeoenvironmental and historical perspective. J. Mediev. Iber. Stud. 2015, 7, 1-17. [CrossRef] 
67. Carrobles, J.; Morín, J.; Rodríguez, S. La génesis de un paisaje medieval II: Los espacios ganaderos bajomedievales. In Alquerías, Cigarrales y Palacios: La Quinta de Mirabel; Carrobles, J., Morín, J., Eds.; AUDEMA S.A.: Toledo, Spain, 2016; pp. 115-134. ISBN 9788416450145.

68. López-Sáez, J.A.; Abel-Schaad, D.; Robles-López, S.; Pérez-Díaz, S.; Alba-Sánchez, F.; Nieto-Lugilde, D. Landscape dynamics and human impact on high-mountain woodlands in the western Spanish Central System during the last three millennia. J. Archaeol. Sci. Rep. 2016, 9, 203-218. [CrossRef]

69. Pastor-de Togneri, R. Del Islam al Cristianismo. En las Fronteras de dos Formaciones Económico-Sociales; Toledo Siglos XI-XIII; Península: Barcelona, Spain, 1985; 186p, ISBN 9788429711479.

70. Izquierdo-Benito, R. Vascos: La Vida Cotidiana en una Ciudad Fronteriza de al-Andalus; Junta de Comunidades de Castilla-La Mancha: Toledo, Spain, 1999; p. 175. ISBN 8477882282.

71. Gerbet, M.C. La Ganadería Medieval en la Península Ibérica; Crítica: Barcelona, Spain, 2002; 281p, ISBN 9788484324164.

72. Bradley, R.S. Climate of the last millenium. In Proceedings of the Holocene Working Group Workshop, Hafslo, Norway, 27-29 August 2003; Bjerknes Centre for Climate Research: Bergen, Norway, 2003.

73. Sánchez-López, G.; Hernández, A.; Pla-Rabes, S.; Trigo, R.M.; Toro, M.; Granados, I.; Sáez, A.; Masqué, P.; Pueyo, J.J.; Rubio-Inglés, M.J.; Giralt, S. Climate reconstruction for the last two millenia in central Iberia: The role of East Atlantic (EA), North Atlantic Oscillation (NAO) and their interplay over the Iberian Peninsula. Quat. Sci. Rev. 2016, 149, 135-150. [CrossRef]

74. Izquierdo-Benito, R. Reconquista y Repoblación de la Tierra Toledana; Diputación provincial de Toledo-Instituto Provincial de Investigaciones y Estudios Toledanos: Toledo, Spain, 1983; 45p, ISBN 0211-4607.

75. Carrobles-Santos, J. El Cuidado del Monte. Evolución de las políticas de protección de la masa forestal en Toledo entre los siglos XIV y XVI. Cuadernos de la SECF 2009, 30, 143-151.

76. Izquierdo-Benito, R. Monografías. Castilla la Mancha en la Edad Media; Servicio de Publicaciones de la JUNTA de Comunidades de Castilla La Mancha: Toledo, Spain, 1985; 160p, ISBN 9788450510485.

77. Martín-Martín, J.L. El campesinado en los Montes de Toledo en los siglos XVIII y XIX. Beresit 2005, 5, 93-121.

78. Pastor-de Togneri, R. La lana en Castilla y León antes de la organización de la Mesta. In Contribución a la Historia de la Trashumancia en España; García Martín, P., Sánchez Benito, J.M., Eds.; Ministerio de Agricultura, Pesca y Alimentación, Secretaría General Técnica: Madrid, Spain, 1996; pp. 363-390. ISBN 9788474794960.

79. Izquierdo-Benito, R. Privilegios Reales Otorgados a Toledo Durante la Edad Media: 1101-1494; Instituto Provincial de Investigaciones y Estudios Toledanos: Toledo, Spain, 1990; 327p, ISBN 9788487103063.

80. Mann, M.E.; Bradley, R.S. Northern Hemisphere Temperatures during the past millenium: Inferences, uncertainties and limitations. Geophys. Res. Lett. 1999, 26, 759-762. [CrossRef]

81. Oliva, M.; Ruiz-Fernández, J.; Barriendos, M.; Benito, G.; Cuadrat, J.M.; Domínguez-Castro, F.; García-Ruiz, J.M.; Giralt, S.; Gómez-Ortiz, A.; Hernández, A.; et al. The Little Ice Age in Iberian mountains. Earth-Sci. Rev. 2018, 177, 175-208. [CrossRef]

82. Jiménez-de Gregorio, F. La Comarca Histórica Toledana de los Montes de Toledo; Instituto Provincial de Investigación y Estudios Toledanos-Diputación de Toledo: Toledo, Spain, 2008; 149p, ISBN 8487103943.

83. De Linares, V.G.G. Los bosques en España a lo largo de la Historia. In Historia de Los Bosques. El Significado de la Madera en el Desarrollo de la Civilización; Perlin, J., Ed.; Gaia Proyecto 2050: Madrid, Spain, 1999; pp. 429-480. ISBN 9788493023218.

84. Domínguez-Castro, F.; Santisteban, J.I.; Barriendos, M.; Mediavilla, R. Reconstruction of drought episodes for central Spain from rogation ceremonies recorded at the Toledo Cathedral from 1506 to 1900: A methodological approach. Glob. Planet. Chang. 2008, 63, 230-242. [CrossRef]

85. Martín-Lou, M.A.; López-Vizoso, J.M.; Martínez-Vega, J. Las actividades forestales en los Montes de Toledo. Anales de Geografía de la Universidad Complutense 1992, 12, 233-241.

86. Martínez-Vega, J. La actual situación de los bosques en la Comarca de los Montes de Toledo. Estud. Geogr. 1990, 51, 577-588.

87. Diago-Hernando, M. Mesta y Trashumancia en Castilla. Siglos XIII-XIX; Arco Libros: Madrid, Spain, 2002; ISBN 8476355181.

88. Bauer-Maanderscheid, E. Los Montes de España en la Historia; Ministerio de Agricultura: Madrid, Spain, 1980; 610p, ISBN 8474790840. 
89. González-González De Linares, V.; García-Viñas, J.I.; Carrero Díez, L.; Cuevas Moreno, J.; González-Doncel, I.; Gil, L. Effects on vegetation of historical charcoal making in central spain: The "Montes de Toledo" case. In Proceedings of the International Conference of the European Rural History Organisation (EURHO), Bern, Switzerland, 19-22 August 2013.

90. Sánchez-Miguel, J.M. Las tenerías o tinterías en los Montes de Toledo. Revista de Estudios Monteños 1988, 42, 25-28.

91. Moreno-Gómez, A.; Rodríguez-Vigal, C.; Ferrandis-Gotor, P.; de las Heras-Ibáñez, J. Impacto del escodado del ciervo (Cervus elaphus L.) sobre la cornicabra (Pistacia terebinthus L.) en «Quintos de Mora》 (Los Yébenes, Toledo). Investig. Agrar. Sist. Recur. For. 2001, 10, 81-93.

92. Orueta, J.F.; Aranda, Y.; García, F.J. Efecto del ramoneo del ciervo (Cervus elaphus) sobre dos especies del matorral mediterráneo en los Montes de Toledo (Centro de España). Galemys SECEM 1998, 10, 27-36.

93. Huerta-González, M. El carbón vegetal en los Montes de Toledo. Revista de estudios Monteños 2006, 114, 8-23.

94. Mercuri, A.M. Genesis and evolution of the cultural landscape in central Mediterranean: The «where, when and how $\gg$ through the palinological approach. Landsc. Ecol. 2014, 29, 1799-1810. [CrossRef]

(C) 2018 by the authors. Licensee MDPI, Basel, Switzerland. This article is an open access article distributed under the terms and conditions of the Creative Commons Attribution (CC BY) license (http:/ / creativecommons.org/licenses/by/4.0/). 